DOI: 10.46340/eppd.2021.8.5.12

Andrii Zhorniak

ORCID ID: https://orcid.org/0000-0001-9515-0180

Dnipropetrovsk regional institute of public administration

of the National Academy for public administration

under the President of Ukraine

Svitlana Podplota, PhD in Pedagogics

ORCID ID: https://orcid.org/0000-0002-5184-9907

Bogdan Khmelnitsky Melitopol State Pedagogical University, Ukraine

\title{
MODERNIZATION OF LOCAL GOVERNMENTS ACTIVITIES REGARDING SOCIAL INTEGRATION OF PERSONS WITH DISABILITIES IN UKRAINE
}

\author{
Андрій Жорняк \\ Дніпропетровський регіональний інститут державного управління \\ Національної академії державного управління при Президентові України \\ Світлана Подпльота, доктор філософії у галузі педагогіки \\ Мелітопольський державний педагогічний університет \\ імені Богдана Хмельницького, Україна

\section{МОДЕРНІЗАЦІЯ ДІЯЛЬНОСТІ ОРГАНІВ \\ МІСЦЕВОГО САМОВРЯДУВАННЯ ЩОДО СОЦІАЛЬНОЇ ІНТЕГРАЦІЇ ОСІБ 3 ІНВАЛІДНІСТЮ В УКРАЇНІ}

The article emphasizes that one of the important features of effective community development is the participation of all groups of citizens in socio-political life. In turn, social policy should create conditions and invest resources aimed at unleashing enormous human potential, including people with disabilities, and promoting their participation in community life. It is proposed to take a set of joint measures to ensure the implementation of joint practical actions, both by the authorities and by public institutions, in order to improve the legal framework to promote social integration of persons with disabilities, expand their rights and opportunities for community participation, improve working conditions, provide employment and career development, overcome stigma and inform other members of society about the importance of integrating people with disabilities into society. Analysis of the existing mechanism of local government activities on social integration of persons with disabilities allowed the authors to create a new structure - the Agency for Social Integration of Persons with Disabilities - which at the local level should coordinate work on social integration of persons with disabilities, based on legislation, new state standards and provide innovative social services. The structure of the Agency, its basic components, purpose, principles, tasks, directions of work, efficiency criteria and evaluation indicators, as well as the expected results are determined. It has been demonstrated that with the participation of the Agency there will be empowerment of persons with disabilities, which will contribute to the development of local communities, the formation of human capital and will have a positive economic effect in the united territorial communities. A comprehensive mechanism for modernizing the activities of local governments on the social integration of persons with disabilities based on a social approach has been developed. The presented organizational and managerial structure includes a set of local governments, whose activities are aimed at the integration of persons with disabilities. The Agency for Social Integration of Persons with Disabilities is responsible for coordinated interaction and 
coordinates the actions of the whole set of measures to ensure the social integration of persons with disabilities.

Keywords: persons with disabilities, social integration, discrimination, social rehabilitation, local governments, modernization, united territorial communities.

Вступ. Сучасний курс державної політики, спрямований на децентралізацію державного управління в Україні, має на меті створення умов для ефективного розвитку громадянського суспільства, спираючись на соціально-політичні рішення органів місцевого самоврядування об’єднаних територіальних громад, що мають забезпечувати цілісність громадянського суспільства як соціальної системи. Рівень розвитку суспільства значною мірою визначається усвідомленим ставленням до найменш захищених та найбільш вразливих його членів, саме тому питання соціальної інтеграції осіб з інвалідністю, захисту їх прав та свобод вважаються актуальними в усьому цивілізованому світі.

Соціальна інтеграція означає «згуртованість та гармонізацію спільноти» та «призводить до посилених та інтенсивних контактів між членами цієї спільноти та їх прийняття для спільних систем цінностей, норм та критеріїв оцінки». Соціальна інтеграція - це не стан, а швидше процес змін, що відбуваються в ментальності людей з інвалідністю та без неї, їх взаємних стосунків та моделей поведінки ${ }^{1}$. Р. Мерфі, Дж. Шеєр, Й. Мерфі та Р. Мак стверджують, що особи з інвалідністю маргінальні для суспільства, вони «стоять на порозі» та готові вступити до нього, але все ще поза його межами르. Особи з інвалідністю стикаються з ситуаціями нерівності та неповаги до гідності, маючи серйозні труднощі для досягнення своєї особистої автономії ${ }^{3}$.

3 підписанням Конвенції $\mathrm{OOH}$ про права інвалідів ${ }^{4}$ Україна взяла на себе зобов'язання розробляти та впроваджувати політику, закони та адміністративні заходи, що забезпечують права, визнані Конвенцією, та скасувати закони, правила, звичаї та практики, що становлять дискримінацію. Незважаючи на те, що органами державної влади та місцевого самоврядування вже зроблені певні кроки, спрямовані на позитивне сприйняття громадськістю інвалідності як суспільного явища, в українському суспільстві, процес зміни стереотипного ставлення до осіб з інвалідністю триває досить повільно та має неоднорідний характер. Сприйняття їх як рівноправних членів суспільства ще не $\epsilon$ загальновизнаним, бракує сучасних підходів до питань посилення інтеграційних процесів осіб з інвалідністю у суспільно-політичне життя. Інвалідність як суспільне явище $є$ важливим питанням розвитку територіальних громад. Оскільки особи з інвалідністю $є$ величезним, продуктивним людським потенціалом в цих питаннях, вони нарівні з іншими громадянами мають вносити свій вклад у створення соціально-економічних благ, i користуватися ними. Політика органів місцевого самоврядування щодо соціальної інтеграції осіб з інвалідністю знаходиться в динамічному стані та стикається 3 певними труднощами, які викликані як певними прогалинами у законодавстві, сферах охорони здоров'я, освіти і науки, соціального забезпечення, фізичної культури та спорту, культури, розвитку громадянського суспільства, архітектури та містобудування, молодіжної політики, так і у загальному відношенні суспільства до інвалідності як соціального явища.

Виклад основного матеріалу. Органи місцевого самоврядування зобов'язані розширити права та можливості осіб з інвалідністю, створити більш сприятливі умови для їх участі в житті спільнот, в обговоренні питань та прийнятті рішень (люди з інвалідністю повинні бути в центрі цих етапів соціальних процесів). Мають бути забезпечені належні умови для отримання якісної освіти, профорієнтаційних послуг, залучення в офіційні трудові відносини. Потрібно вжити комплекс

\footnotetext{
${ }^{1}$ Twardowski, A. (2014). Barriers to Social Integration for People with Disabilities. The Polish Experiences. Studia Edukacyjne, 30, 119-130 <https://repozytorium.amu.edu.pl/bitstream/10593/12330/1/art07_Twardowski\%20A.pdf> (2021, серпень, 22).

${ }^{2}$ Murphy, R. F., Scheer, J., Murphy, Y., Mack, R. (1988). Physical Disability and Social Liminality: A Study in the Rituals of Adversity. Social Science and Medicine, 26 (2), 235-242.

${ }^{3}$ Anaut, S., et al. (2014). La incidencia de la exclusión social en los hogares con personas con discapacidad. VII Informe sobre exclusión y desarrollo social en España. Serie: Documento de Trabajo, Madrid, Fundación FOESSA, Cáritas Española Editores, 29.

${ }^{4}$ United Nations General Assembly (2006). Convention on the Rights of Persons with Disabilities, 61, <https://www.un.org/development/desa/disabilities/convention-on-the-rights-of-persons-with-disabilities.html> (2021, серпень, 22).
} 
спільних заходів на всіх рівнях для забезпечення впровадження спільних практичних дій як зі сторони державних органів влади, законодавчих та виконавчих, так і зі сторони громадських інституцій.

Стаття 46 Конституції України ${ }^{1}$ передбачає право громадян на соціальний захист, зокрема через створення мережі державних, комунальних, приватних закладів. Наголошуємо на необхідності змін у підходах до управління діяльністю відділів та структурних підрозділів органів місцевого самоврядування, соціальних служб, розроблення додаткових механізмів та заходів, спрямованих на покращення якості життя мешканців територіальних громад, прийняття нових нормативних документів, що регулюють зміст і процедури процесів інтеграції осіб з інвалідністю, запобігання соціального відчуження, а також удосконалення методології оцінювання і моніторингу поточного стану за певними індикаторами.

У зв'язку із необхідністю оптимізувати систему надання соціальних послуг в умовах обмеження фінансових ресурсів територіальних громад пропонуємо створення нової структури Агенції соціальної інтеграції осіб з інвалідністю, - яка на місцевому рівні має координувати роботу надання соціальних послуг особам з інвалідністю, забезпечивши ефективну взаємодію усіх надавачів послуг, націлену на спільний результат, підвищуючи тим самим адресність соціальної підтримки. Метою нової організаційно-управлінської структури $\epsilon$ виконання запропонованого стратегічного плану, спираючись на законодавчу базу, сучасний виклик держави щодо апробації нових державних стандартів та надання інноваційних соціальних послуг.

Агенція соціальної інтеграції осіб з інвалідністю може мати асоціативну структуру 3 декількома окремими підрозділами для забезпечення безперервності, наступності та різноманітності соціальних послуг, направлених на інтеграцію осіб з інвалідністю у суспільство. Фактичні надавачі цих послуг взаємодіють між собою, а також з органами місцевого самоврядування, організаціями, фондами, установами, закладами системи соціального захисту, охорони здоров'я, освіти, науки, правоохоронними органами тощо (див. рис. 1).

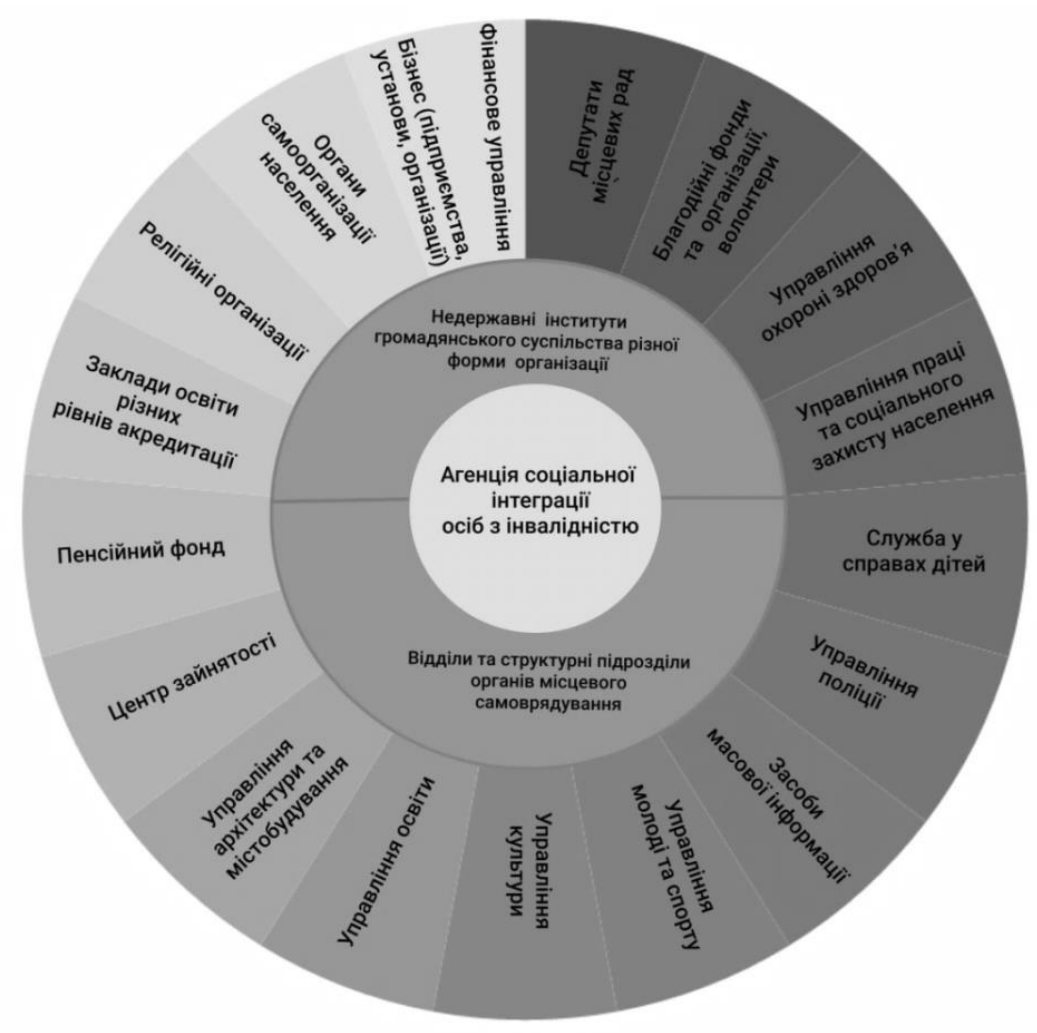

Рис. 1. Схема взаємодії Агенції соціальної інтеграції осіб з інвалідністю.

Джерело: розроблено авторами

\footnotetext{
${ }^{1}$ Конституиія України, 1996 (Відомості Верховної Ради України). Офіиіийний сайт Верховної Ради Украӥни <https://zakon.rada.gov.ua/laws/show/254\%D0\%BA/96-\%D0\%B2\%D1\%80\#Text> (2021, серпень, 22).
} 
Механізм діяльності органів місцевого самоврядування щодо соціальної інтеграції осіб 3 інвалідністю визначаємо як комплексну взаємоузгоджену систему заходів для забезпечення включення осіб з інвалідністю у суспільно-політичне життя, яка включає законодавче, економічне, соціально-психологічне підгрунтя, фінансово-економічний вплив i організаційно-управлінську структуру. Для ефективного функціонування системи необхідна узгоджена взаємодія та координація дій усього комплексу заходів для забезпечення інтеграції осіб з інвалідністю. Цю функцію буде виконувати новостворена структура - Агенція соціальної інтеграції осіб з інвалідністю. Така всебічність програмно-цільового управління процесами інтеграції відповідає розумінню роботи системи органів місцевого самоврядування як елементу цілісної державної системи управління.

Наголошуємо на необхідності розроблення Регіональної стратегії інтеграції осіб з інвалідністю, де мають бути визначені цілі, завдання, пріоритети, механізми підзвітності та контролю, індикатори оцінки, способи реалізації напрямів регіональної політики в питаннях інтеграції осіб з інвалідністю відповідно до наявних ресурсних можливостей громад, що сприятиме удосконаленню та врегулюванню таких аспектів, як: усунення дискримінації та стигматизації, створення умов для позитивного ставлення громадськості до інвалідності як суспільного явища. Розроблена місцева стратегія має стати дієвим інструментом та ефективним механізмом управління інтеграції осіб з інвалідністю у суспільно-політичне життя.

Суб'єктами впливу на процес інтеграції осіб з інвалідністю є: органи місцевого самоврядування та їх підрозділи, недержавні інститути громадянського суспільства, що опікуються інтеграцією осіб з інвалідністю. До повноважень Агенції соціальної інтеграції осіб з інвалідністю належить:

- аналіз поточного стану та прогнозування тенденцій у сфері інтеграції осіб з інвалідністю у суспільне життя територіальної громади;

- моніторинг, реалізація та корегування стратегічного плану щодо інтеграції осіб 3 інвалідністю;

- аналіз ресурсного потенціалу територіальної громади для забезпечення соціальної інтеграції осіб з інвалідністю;

- постійний та систематичний моніторинг економічної спроможності територіальної громади виконувати заходи місцевих програм, спрямованих на соціальну інтеграцію осіб з інвалідністю;

- розроблення i виконання довготермінової стратегії соціальної інтеграцію осіб з інвалідністю, враховуючи сучасні виклики та ресурс територіальної громади;

- формування рекомендацій щодо місцевої політики, спрямованої на інтеграцію осіб 3 інвалідністю;

- підготовка рекомендацій щодо інтеграції осіб 3 інвалідністю для виконавчих органів місцевого самоврядування;

- забезпечення взаємодії інститутів громадянського суспільства, що опікуються особами 3 інвалідністю, з органами місцевого самоврядування та їх структурними підрозділами, фінансовими установами, науковими установами, іншими організаціями;

- експертиза місцевих програм щодо їх відповідності основним пріоритетам регіональної стратегії інтеграції осіб з інвалідністю;

- оцінка виконання місцевих програм, спрямованих на інтеграцію осіб з інвалідністю.

Агенція соціальної інтеграції осіб з інвалідністю визначає пріоритети надання соціальних послуг; розробляє пропозиції до програм, спрямованих на інтеграцію осіб з інвалідністю у суспільств; забезпечує осіб з інвалідністю та їх сімей інноваційними соціальними послугами. 3 метою проведення ефективної роботи фахівці Агенції соціальної інтеграції осіб з інвалідністю зобов'язані вести облік проблемних питань, інформація до яких надходить як із установ органів місцевого самоврядування та їх структурних підрозділів, недержавних організацій, а також особисто від осіб з інвалідністю.

Агенція соціальної інтеграції осіб з інвалідністю має стати основною ланкою визначення потреб осіб з інвалідністю територіальної громади; аналізу існуючих організацій, їх можливостей; наявності фахових спеціалістів, що надають соціальні послуги; стратегічних напрямів обслуговування осіб з інвалідністю громади; шляхів консолідації зусиль місцевої влади та інститутів громадянського суспільства щодо реалізації заходів спрямованих на інтеграцію осіб з інвалідністю.

Запропонована організаційно-управлінська структура є системою соціального обслуговування осіб з інвалідністю повного циклу, охоплює всі категорії та вікові групи осіб з інвалідністю, згідно 
визначених законодавством нозологій та спрямована на впровадження інноваційних послуг, враховуючи питання раціонального та ефективного використання бюджетних коштів, забезпечуючи впровадження заходів, що сприятимуть:

- чіткому плануванню послуг на потреби населення;

- централізованому веденню документообігу;

- централізованій роботі бухгалтерії;

- можливості використовувати матеріально-технічну базу структурних підрозділів органів місцевого самоврядування;

- оптимізації звітності;

- виключення дублювання функцій;

- зменшення документообігу, переписки між службами.

Агенція соціальної інтеграції осіб співпрацює із структурними підрозділами органів місцевого самоврядування, залишаючи за ними функцію головних надавачів цих послуг, забезпечує виконання заходів діючих програм, що спрямовані на інтеграцію осіб з інвалідністю. Крім того Агенція соціальної інтеграції осіб з інвалідністю вивчає передовий досвід об'єднаних територіальних громад в області реабілітації осіб з інвалідністю та впроваджує запропоновані державою інноваційні види соціальних послуг, на приклад «Державний стандарт соціальної послуги представництва інтересів» ${ }^{1}$, «Державний стандарт соціальної послуги підтриманого проживання осіб похилого віку та осіб 3 інвалідністю» ${ }^{2}$, «Державного стандарту соціальної послуги соціального супроводу при працевлаштуванні та на робочому місці» ${ }^{3}$ тощо.

Агенція соціальної інтеграції осіб з інвалідністю відповідно до покладених на неї обов'язків, враховуючи процеси децентралізації, та відповідно до державних стандартів, сучасних викликів, в рамках своїх повноважень постійно підвищує компетентність своїх фахівців та забезпечує комплексність та якість виконання місцевих програм, спрямованих на соціальну інтеграцію осіб 3 інвалідністю. У той же час Агенція соціальної інтеграції осіб з інвалідністю фактично, спрямовуючи роботу та надаючи практичну й методичну допомогу, виключаючи дублювання функцій та фінансових ресурсів структурних підрозділів органів місцевого самоврядування та концентруючи їх в одній структурі, забезпечує повну соціальну підтримку за принципом «єдиного вікна».

Крім того фахівцями Агенції соціальної інтеграції осіб з інвалідністю впроваджується обслуговування громадян на дому та налагоджується тісна співпраця з дільничними інспекторами, лікарями, головами квартальних комітетів. Це дає можливість вивчати потреби більшої кількості осіб з інвалідністю та здійснювати контроль за належним виконанням заходів міських програм, спрямованих на соціальну інтеграцію осіб з інвалідністю. Також одним із завдань Агенції соціальної інтеграції осіб з інвалідністю $є$ оцінка потреб осіб з інвалідністю або сімей осіб з інвалідністю об’єднаної територіальної громади, які потребують допомоги, що забезпечить ефективність використання бюджетних коштів, кадрів та допоможе оптимізувати питання розв'язання їх соціальних проблем.

Одним з ефективних методів дослідження, що дає відображення сучасного стану у сфері інтеграції осіб з інвалідністю територіальної громади, є проведення фахівцями Агенції соціальної інтеграції осіб з інвалідністю подвірного обходу, складання соціальних паспортів сімей осіб з інвалідністю, виявлення осіб з інвалідністю, не охоплених соціальним супроводом, започаткування роботи громадських приймалень, забезпечення засобіами інформування населення (створення сайту Агенції соціальної інтеграції осіб з інвалідністю, міських телевізійних програм, Інтернетприймальні, мобільних додатків та інших засобів), впровадження спрощеної системи надання соціальної допомоги, пільг та субсидій.

\footnotetext{
${ }^{1}$ Наказ про затвердження Державного стандарту соиіальної послуги представництва інтересів, 2015 (Мінсоцполітики України). Офіиійний сайт Верховної Ради Украӥни <https://zakon.rada.gov.ua/laws/show/z0127-16\#Tеxt> (2021, серпень, 22).

${ }^{2}$ Наказ про затвердження Державного стандарту соиіальної послуги підтриманого прожсивання осіб похилого віку та осіб з інвалідністю, 2017 (Мінсоцполітики України). Офіційний сайт Верховної Ради Украӥни <https://zakon.rada.gov.ua/laws/show/z0806-17\#Tеxt> (2021, серпень, 22).

${ }^{3}$ Наказ про затвердження Державного стандарту соиіальної послуги соиіального супроводу при працевлаштуванні та на робочому місиі, 2016 (Мінсоцполітики України). Офіційний сайт Верховної Ради Украӥни <https://zakon.rada.gov.ua/laws/show/z1359-16\#Text> (2021, серпень, 22).
} 
У структурі Агенції соціальної інтеграції осіб з інвалідністю пропонуємо забезпечити роботу Відділення благодійної діяльності, завданням якого є налагодження співпраці з міжнародними благодійними фондами, залучення коштів підприємств, установ та організацій міста для надання матеріальної та натуральної допомоги особам з інвалідністю. Агенція соціальної інтеграції осіб 3 інвалідністю співпрацює з мережею структурних підрозділів органів місцевого самоврядування усферах охорони здоров'я, освіти та науки, культури, молодіжної політики, соціального забезпечення, фізичної культури та спорту, розвитку громадянського суспільства, містобудування та архітектури на рівні об'єднаної територіальної громади.

Агенція соціальної інтеграції осіб з інвалідністю у сфері охорони здоров'я співпрацює з місцевими відділами охорони здоров'я. Спільна діяльність Агенції соціальної інтеграції осіб 3 інвалідністю з місцевими відділами у сфері охорони здоров'я спрямована на надання спеціалізованої кваліфікованої медичної допомоги особам з інвалідністю, здійснення управління медичним обслуговуванням таких осіб, надання комплексу медико-соціальних заходів, спрямованих на захист здоров'я осіб з інвалідністю.

Послуги усфері реабілітації осіб з інвалідністю здійснюють Центри реабілітації, що обслуговують та забезпечують повний цикл реабілітації інвалідів впродовж життя. Агенція соціальної інтеграції осіб з інвалідністю допомагає Центрам в організації реабілітації, оздоровлення, відпочинку та дозвілля. Фахівці Агенції соціальної інтеграції осіб з інвалідністю разом із співробітниками Центра медико-соціальної та професійно-трудової реабілітації інвалідів займаються впровадженням інклюзивного реабілітаційного туризму, як одного з активних видів реабілітації. Фахівцями розробляються маршрути інклюзивного туризму для осіб з інвалідністю, які користуються інвалідними візками. Передбачено перевезення учасників екскурсії спеціальним транспортом із підйомниками. Фахівцями Агенції соціальної інтеграції осіб з інвалідністю ініціюються та впроваджуються міські програми 3 надання послуг 3 перевезення осіб з інвалідністю, такі як «Соціальні перевезення», «Соціальне таксі» тощо.

У сфері освіти та науки Агенція соціальної інтеграції осіб з інвалідністю співпрацює 3 місцевими управліннями освіти та їх структурними підрозділами. Спільна діяльність спрямована на збереження та зміцнення фізичного, психічного і духовного здоров'я осіб з інвалідністю; всебічний розвиток, навчання, розвиток творчих здібностей осіб з інвалідністю; набуття соціального досвіду, забезпечення соціальної адаптації та соціальної інтеграції осіб з інвалідністю; професійне самовизначення осіб з інвалідністю та готовність продовжувати навчання упродовж життя; надання методичної допомоги педагогічним працівникам дошкільних, загальноосвітніх та професійнотехнічних навчальних закладів щодо особливостей здійснення психолого-педагогічної допомоги дітям з інвалідністю та ін.

Разом з Управлінням соціального захисту населення та його структурними підрозділами Агенція забезпечує надання соціальних послуг, соціальний патронаж осіб з інвалідністю. Крім того до повноважень фахівців Агенції соціальної інтеграції осіб з інвалідністю входить співпраця 3 Управлінням молоді та спорту та інституціями, що надають послуги у цій сфері, залучаючи фахівців сфери фізичної культури та спорту для розробки моделі фізкультурно-спортивної реабілітації та організації змагань з видів спорту, охоплюючи всі існуючи нозології та вікові категорії осіб з інвалідністю, що мешкають в територіальній громаді.

Співпрацюючи з Управлінням культури, фахівці Агенції соціальної інтеграції осіб з інвалідністю залучають до реалізації спільних заходів, спрямованих на інтеграцію осіб з інвалідністю, професійних, творчих, наукових працівників, зокрема, музейних, бібліотечних закладів, історико-культурних заповідників, архівних установ, педагогічних працівників закладів освіти сфери культури, митців, що працюють на засадах мистецького аматорства, працівників закладів культури, професійних та творчих спілок, товариств, фондів, асоціацій, а також підприємств, установ та організацій усіх форм власності. Робота Агенції соціальної інтеграції осіб 3 інвалідністю у сфері культури спрямована на забезпечення охорони об'єктів культурної спадщини, створення єдиного культурного простору та збереження цілісності культури, сприяння мистецького аматорства та організацію дозвілля осіб з інвалідністю.

Співпрацюючи з Відділом з питань планування та забудови міста, Відділом містобудівного кадастру Агенція соціальної інтеграції осіб з інвалідністю забезпечує реалізацію державної політики у сфері містобудування та архітектури на міському рівні, здійснює регулювання діяльності суб'єктів містобудування щодо комплексного розвитку територій, забудови міста, забезпечення прав осіб 
3 інвалідністю, спрямованих на підвищення якості житлового середовища, здійснення контролю за містобудівною діяльністю та будівництвом, організацією нового будівництва та реконструкцією існуючих житлових будинків, об'єктів соціально-побутового призначення.

Висновки. Аналіз існуючих практик надання особам з інвалідністю соціальних послуг засвідчує, що у кожній об'єднаній територіальній громаді є своя специфіка взаємовідносин з особами з інвалідністю, яка залежить не тільки від ресурсу громади, а й від ставлення суспільства до інвалідності, як суспільного явища. Тож не існує універсальної моделі соціального обслуговування, яка б підходила всім територіальним громадам. Саме тому у кожній територіальній громаді повинна бути сформована власна модель взаємовідносин органів місцевого самоврядування з особами з інвалідністю, що буде враховувати принцип ефективної взаємодії в умовах можливостей та існуючих ресурсів територіальної громади. Розширення можливостей осіб з інвалідністю сприятиме процесам розвитку територіальних громад, формуванню людського капіталу та матиме позитивний економічний ефект в об'єднаних територіальних громадах.

Вважаємо, що запропонована організаційно-управлінська система спроможна забезпечити охоплення більшої кількості осіб з інвалідністю соціальними послугами та сприятиме їх інтеграції осіб суспільство. Вона є найбільш оптимальною в умовах об'єднання територіальних громад, має дати позитивні результати і заслуговує на застосування, адже спроможна забезпечити реалізацію місцевої політики у сферах охорони здоров'я, освіти та науки, культури, молодіжної політики, соціального забезпечення, фізичної культури та спорту, розвитку громадянського суспільства, містобудування та архітектури на рівні об’єднаної територіальної громади.

\section{References:}

1. Twardowski, A. (2014). Barriers to Social Integration for People with Disabilities. The Polish Experiences. Studia Edukacyjne, 30, 119-130. <https://repozytorium.amu.edu.pl/bitstream/10593/12330/1/art07_ Twardowski\%20A.pdf> (2021, August, 22). [in English].

2. Murphy, R. F., Scheer, J., Murphy, Y., Mack, R. (1988). Physical Disability and Social Liminality: A Study in the Rituals of Adversity. Social Science and Medicine, 26 (2), 235-242 [in English]

3. Anaut, S., et al. (2014). La incidencia de la exclusión social en los hogares con personas con discapacidad [The incidence of social exclusion in households with people with disabilities]. VII Informe sobre exclusión y desarrollo social en España. Serie: Documento de Trabajo [VII Report on exclusion and social development in Spain. Series: Working Document]. Madrid, FOESSA Foundation, Cáritas Española Editores [in Spanish].

4. United Nations General Assembly (2006). Convention on the Rights of Persons with Disabilities $<$ https://www.un.org/development/desa/disabilities/convention-on-the-rights-of-persons-with-disabilities.html> (2021, August, 22). [in English].

5. Konstytutsiia Ukrainy, 1996 (Vidomosti Verkhovnoi Rady Ukrainy) [Constitution of Ukraine, 1996 (Bulletin of the Verkhovna Rada of Ukraine)]. Ofitsiynyy sayt Verkhovnoyi Rady Ukrayiny [The official website of the Verkhovna Rada of Ukraine] 〈https://zakon.rada.gov.ua/laws/show/254\%D0\%BA/96-\%D0\%B2\%D1\%80\#Text> (2021, August, 22). [in Ukrainian].

6. Nakaz pro zatverdzhennya Derzhavnoho standartu sotsialnoyi posluhy predstavnytstva interesiv, 2015 (Minsotspolityky Ukrayiny) [Order on approval of the State standard of social service of representation of interests, 2015 (Ministry of Social Policy of Ukraine)]. Ofitsiynyy sayt Verkhovnoyi Rady Ukrayiny [The official website of the Verkhovna Rada of Ukraine]. <https://zakon.rada.gov.ua/laws/show/z0127-16\#Text> (2021, August, 22). [in Ukrainian].

7. Nakaz pro zatverdzhennya Derzhavnoho standartu sotsialnoyi posluhy pidtrymanoho prozhyvannya osib pokhyloho viku ta osib z invalidnistyu, 2017 (Minsotspolityky Ukrayiny) [Order on approval of the State standard of social service of supported living for the elderly and people with disabilities, 2017 (Ministry of Social Policy of Ukraine)]. Ofitsiynyy sayt Verkhovnoyi Rady Ukrayiny [The official website of the Verkhovna Rada of Ukraine]. <https://zakon.rada.gov.ua/laws/show/z0806-17\#Text> (2021, August, 22). [in Ukrainian].

8. Nakaz pro zatverdzhennya Derzhavnoho standartu sotsialnoyi posluhy sotsialnoho suprovodu pry pratsevlashtuvanni ta na robochomu mistsi, 2016 (Minsotspolityky Ukrayiny) [Order on approval of the State standard of social service of social support at employment and at work, 2016 (Ministry of Social Policy of Ukraine)]. Ofitsiynyy sayt Verkhovnoyi Rady Ukrayiny [The official website of the Verkhovna Rada of Ukraine]. <https://zakon.rada.gov.ua/laws/show/z1359-16\#Text> (2021, August, 22). [in Ukrainian]. 